\title{
Ruimtelijke differentiatie in het kiesgedrag van een stedelijke bevolking. De Leuvense verkiezingen 1987-1995
}

Spatial differentiation of the voting behaviour of an urban population. Elections in Leuven (Louvain) 1987-1995

\section{Herman Van der Haegen}

\section{(2) OpenEdition}

\section{Journals}

Édition électronique

URL : http://journals.openedition.org/belgeo/15359

DOI : 10.4000/belgeo.15359

ISSN : 2294-9135

\section{Éditeur :}

National Committee of Geography of Belgium, Société Royale Belge de Géographie

Édition imprimée

Date de publication : 30 juin 2001

Pagination : 77-92

ISSN : 1377-2368

Référence électronique

Herman Van der Haegen, «Ruimtelijke differentiatie in het kiesgedrag van een stedelijke bevolking. De Leuvense verkiezingen 1987-1995», Belgeo [Online], 1-2 | 2001, Online op 30 novembre 2001,

geraadpleegd op 03 mai 2019. URL : http://journals.openedition.org/belgeo/15359; DOI : 10.4000/ belgeo.15359

Ce document a été généré automatiquement le 3 mai 2019.

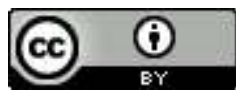

Belgeo est mis à disposition selon les termes de la licence Creative Commons Attribution 4.0 International. 


\section{Ruimtelijke differentiatie in het kiesgedrag van een stedelijke bevolking. De Leuvense verkiezingen 1987-1995}

Spatial differentiation of the voting behaviour of an urban population. Elections in Leuven (Louvain) 1987-1995

Herman Van der Haegen

\section{Geografische relevantie van de analyse van het kiesgedrag in een stad en vraagstelling}

Politieke ruimtelijke patronen zijn de belangstelling van de stadsgeograaf om meerdere redenen waard. Enerzijds treden er in het stempatroon binnen onze steden sterke ruimtelijke verschillen op die bepaald worden door historische en vooral sociaaleconomische elementen. Anderzijds is het ook zo dat ruimtelijke verschillen in het kiesgedrag in het verleden hebben geleid tot een andere politieke samenstelling van de beleidsorganen in de huidige deelgemeenten van onze steden. Verschillen die uiteraard hun stempel hebben gedrukt op het beleid. Dit vertaalde zich dan weer in het landschap onder meer door omvang en ouderdom van de sociale woningbouw maar ook door de graad van permissiviteit bij de stedenbouw en bij de milieuzorg in het algemeen. Mede daardoor is de omvang en vorm van de nieuwe gemeenten (1977) dikwijls bepaald door het kiesgedrag- of verondersteld kiesgedrag om precies te zijn - van bepaalde deelgemeenten of wijken. Door de aanwezigheid van een bepaalde partij (de C.V.P.) die uitgaande van een confessionele basis de verschillende sociale groepen tracht te integreren, zijn de ruimtelijke politieke patronen binnen het stedelijk weefsel in Vlaanderen nog minder duidelijk dan in landen waar dit niet het geval is. Het scheen in ieder geval toch interessant voor een middelgrote stad, waar tussen de verschillende deelgemeenten vrij sterke politieke verschillen bestonden, te onderzoeken hoe de 
toestand er uitziet nu de vroeger zelfstandige deelgemeenten opgegaan zijn in een groter geheel.

Bij de vraagstelling wordt beoogd een antwoord te geven op het volgende :

a. Is er een verband tussen de verkiezingsuitslagen en de socio-economische structuur van de kieswijken en bijkomend in welke mate werden de kiesverwachtingen die een belangrijke rol speelden bij de definitieve vormgeving van het nieuwe Leuven in 1977 gerealiseerd?

b. Is de engere betrokkenheid van de burger bij de lokale bestuurders aanwijsbaar bij de gemeenteraadsverkiezingen en meer speciaal, is de impact van een aantal kandidaten- door hun lokale of nationale inzet en bekendheid - merkbaar?

\section{Bron van de kiesresultaten per wijk}

De lijsten van de stemgerechtigden - in België tevens stemplichtigen - zijn openbaar en alfabetisch geordend op de familienaam. De stemgerechtigden moeten - om de controle vlot te laten verlopen - in stembureaus gaan stemmen die telkens een aantal letters van het alfabet omvatten dus alle kiezers waarvan de familienaam met een a, b, c, d, e... begon in bureau $1 \mathrm{enz}$. Daar alle stem-bureaus in de grootste gemeenten niet op een plaats (gewoonlijk een school) konden worden gevestigd leidde dit in vele gemeenten tot een druk heen-en-weer geloop op de verkiezingsdag. Als reactie hierop, en zeker na de samenvoeging van de gemeenten in 1977, en mede dank zij de informatica werden de nog steeds alfabetische geordende kiezerslijsten nu in de meeste grote gemeenten ook opgesteld per kieswijk, waardoor de verplaatsingen beperkt werden.

werd aldus na de samenvoeging in 1977 onderverdeeld in 23 kies- of stemwijken met ieder een stemlokaal. Afhankelijk van de bevolkingsomvang werden er per kieswijk 1 tot 6 stembureaus gevestigd. Gemiddeld brachten een 600-tal personen hun stem uit per bureau. Voor geheel Leuven waren er 93 stembureaus. De kieswijken zijn in Leuven nog zo omvangrijk dat ze niet alleen meerdere statistische sectoren (de kleinste deelgebieden waarvoor volkstellingsgegevens beschikbaar zijn) maar ook, mede door de recente residentiële ontwikkeling, meestal buurten met uiteenlopende sociale status omvatten. Dit uit zich ook in de verkiezingsresultaten.

Daar de kieswet wil vermijden dat de resultaten per wijk (en voor het parlement per gemeente) bekend worden, waren de Leuvense verkiezingsoperaties zo georganiseerd dat in 32 opnemings-of telbureaus telkens de kiesurnen uit verschillende kieswijken werden geteld, dus bijvoorbeeld telbureau 1: een urn van een bureau uit wijk 1, 5 en 6; telbureau 2 een urn van wijk 1, 3 en 20; enz. De voorzitters van de telbureaus werden verondersteld de kiesbulletins van de verschillende stembureaus te mengen en dan tot de telling over te gaan. De resultaten per partij, maar ook het aantal voorkeurstemmen per kandidaat, werden pas daarna medegedeeld aan het hoofdbureau. Dit alles was bij de manuele telling een zeer tijdrovende en moeizame operatie die gecontroleerd werd door de getuigen van iedere partij en tot diep in de nacht kon uitlopen. Hertellingen waren vrij normaal en werden secuur door de partijgetuigen opgevolgd.

Om de teloperaties zo vlug mogelijk en zo correct mogelijk te doen verlopen en de tijdsinzet bij mogelijke vergissingen te beperken mengde een ervaren voorzitter van een telbureau de urnen van de verschillende bureaus niet. Dit geschiedde met instemming van tellers en getuigen die liefst hun «burgerplicht» niet tot een gevorderd avondlijk uur verlengd zagen. Men telde tegen de onderrichtingen in, per urn (stembureau). De 
getuigen noteerden deze uitslagen zorgvuldig. De voorzitter telde dan de resultaten van de onderscheiden stembureaus samen en vermelde enkel dit officieel eindresultaat aan het hoofdbureau van de gemeente (of het kieskanton bij provinciale-, gewest- of parlementsverkiezingen).

7 De getuigen - vooral van de grootste en meestal best georganiseerde partijen - deelden de officieuze resultaten per stembureau mede aan het partijbestuur. Daar werden ze gehergroepeerd en berekend per wijk. De partijen - vooral de partijstrategen - waren hierin om verschillende redenen (onder meer bij de evolutie van het stemmenaantal en de impact van de voorkeursstemmen) sterk geïnteresseerd. De interesse voor lokale uitslagen is trouwens vrij universeel. Men name bij de gerrymandering (de hertekening van de kiesdistrikten zodat een bepaalde partij een maximum aan zetels bekomt) is dit van belang. Dit gebeurt nu weer in de V.S.A. bij de hertekening van de kiesdistricten in die staten waar het aantal congreszetels zal worden gewijzigd als gevolg van het publiceren van de resultaten van de volkstelling 2000.

8 We zijn de politici, die deze officieuze gegevens mededeelden bijzonder dankbaar. Daar bij de laatste $(1999,2000)$ verkiezingen in Leuven overgeschakeld werd van manueel naar elektronisch stemmen waarvan de diskettes per bureau rechtstreeks aan het hoofdbureau bezorgd werden, zijn de resultaten per wijk mij niet meer bekend.

\section{Vorming van het nieuwe Leuven}

9 Het huidige Leuven (2000: 88.000 inwoners) ontstond op 1.1.1977 door samenvoeging van de gemeenten Leuven (26.000 inwoners), Heverlee (20.000 inwoners), Kessel-Lo (26.000 inwoners), Wilsele (9.000 inwoners), evenals het deel van Herent dat aan het kanaal lag namelijk Wijgmaal (3.000 inwoners) en in het zuidoosten tussen autoweg en de Tiensesteenweg delen van Blanden, Haasrode en Korbeek-Lo, die o.m. het nieuwe bedrijventerrein «Haasrode» omvatte (4.000 inwoners). De bevolking per statistische sector wordt weergegeven in figuur 1. 
Figuur 1. Leuvense bevolking per buurt en oude deelgemeenten.

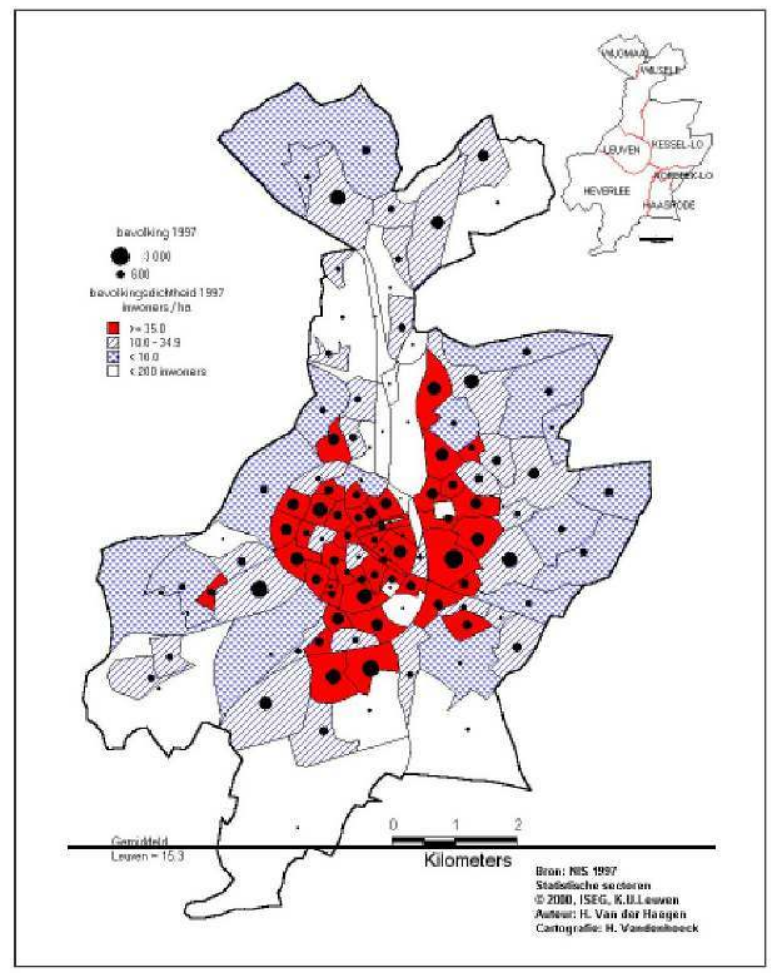

Met de samenvoeging van de gemeenten beoogde men naast het creëren van een voldoende massa (mensen en bedrijven) om een moderne stad te laten functioneren, ook de ganse geografische stad met expansiemogelijkheden te omvatten. In feite was dit in Leuven een late maar noodzakelijke correctie op de beperking van Leuven tot het gebied binnen de wallen ten tijde van de Franse overheersing die de administratieve gemeenten in ons land creëerde en vorm gaf (einde $18^{\text {de }}$ eeuw).

De optimale ruimtelijke vormgeving van de nieuwe gemeenten in 1977 werd op vele plaatsen beperkt door de verwachtingen die de politici hadden ten aanzien van het kiesgedrag in bepaalde gemeenten en delen van gemeenten. Deze invloeden hebben samen met de vorm van de oude deelgemeenten, die dikwijls teruggingen tot de agrarische dorpsbehorens, de eigenaardige vorm die de stad Leuven, vooral in het noorden aanneemt, bepaald. Leuven is als het ware een lichaam met een stevige basis (zijn staart dankt het aan Heverleebos), waarvan de rechterschouder ontbreekt en die over een tweedelig hoofd beschikt.

Er zij hier slechts vermeld dat bij de hierop volgende verkiezingen de verkiezingsuitslagen en voornamelijk de vorming van de schepencolleges veelal anders uitvielen dan diegenen die het nieuwe Leuven en de nieuwe randgemeenten uittekenden, verwacht hadden. Wat er ook van zij Leuvense wijken, die volledig geïntegreerd zijn in de Leuvense leefwereld zoals Diependaal (Herent), Attenhoven (Holsbeek), het grote Leuvense handelscomplex dat zich rond de G.B. op de Tiensesteenweg (nu Bierbeek) ontwikkelde, evenals de villawijken van Leuven te Linden, bleven buiten het nieuwe Leuven. 


\section{Sociaal-economische structuur van de stad}

13 Leuven is als regionale stad uiteraard een belangrijk handels- en dienstencentrum. De universiteit en de ziekenhuizen, de zeer belangrijke financiële (bank en verzekeringen) K.B.C.-groep en andere financiële diensten, een buitengewoon groot aantal instellingen van hoger en secundair onderwijs, nationale en regionale besturen maken er een van de meest tertiaire steden van Vlaanderen . De industriële sector die zeer belangrijk was voor de ontwikkeling van de stad in de $19^{\text {de }}$ eeuw en voornamelijk gelokaliseerd was langs vaart en spoorweg en verspreid in de binnenstad is in sterke regressie. Belangrijk bleef, maar met sterk verminderde tewerkstelling de brouwerij en een aantal fabrieken in de nieuwe bedrijfzones, die echter de regressie van de industrie als tewerkstellingssector niet konden ombuigen.

De ruimtelijke sociale structuur van Leuven wordt nog in grote lijnen bepaald door de historische componenten: «vaart-spoorweg» in het noorden enerzijds en «campus-bos» in het zuiden en in mindere mate door de beboste heuvels rond de stad. Waar de versnipperde bosranden vroeger de minder begoede landelijke bevolking herbergden vormen ze nu residentieel gewaardeerde locaties(zie noorden van Kessel-Lo).Vooral in het centrum en noorden van de binnenstad is de arbeiders-en bediendebevolking nadrukkelijk aanwezig. Dit deel van de bevolking treffen we vooral aan in naoorlogse sociale flatgebouwen en in oudere sociale of privé rijbewoning. In het centrum, maar vooral in het zuiden van de binnenstad wonen de meer welstellenden, voor zoverre ze de binnenstad niet verlaten hebben voor de rand. De alom aanwezigheid van studio's en kleinere appartementen, die vooral bewoond worden door studenten en de Leuvense maar ook uit de nabije en verdere omgeving komende groep minderbedeelden, drukt uiteraard het gemiddeld welstandsniveau van de binnenstad, waar anderzijds een groeiend aantal luxueuse flatgebouwen op uitgekozen sites wijzen op een beginnende gentryfication.

15 Het sociaal gedifferentieerd woonmilieu van de Leuvenaars uit zich echter vooral buiten de binnenstad door de onderling sterk verschillende individuele woningbouw, de grote sociale tuinwijken van verschillende origine en aard in Heverlee, Kessel-Lo en Wilsele, de kleinere en grotere villaverkavelingen aan de randen van de bossen en het verrassend gaaf gebleven agrarisch milieu.

16 Het gemiddeld inkomen per inwoner (fig. 2), waarvan het ruimtelijk patroon verduidelijkt wordt door de bevolkingssprei-ding (fig. 1) illustreert het best deze sociaal gedifferentieerde structuur. Te noteren is aldus dat de twee zuidelijke buurten met geringer inkomen enerzijds de Arenberg-campus is, waar een aantal studenten officieel wonen, en anderzijds het militair domein met o.m. huisvesting voor gezinnen van militairen. 
Figuur 2. Inkomen per inwoner (1996).

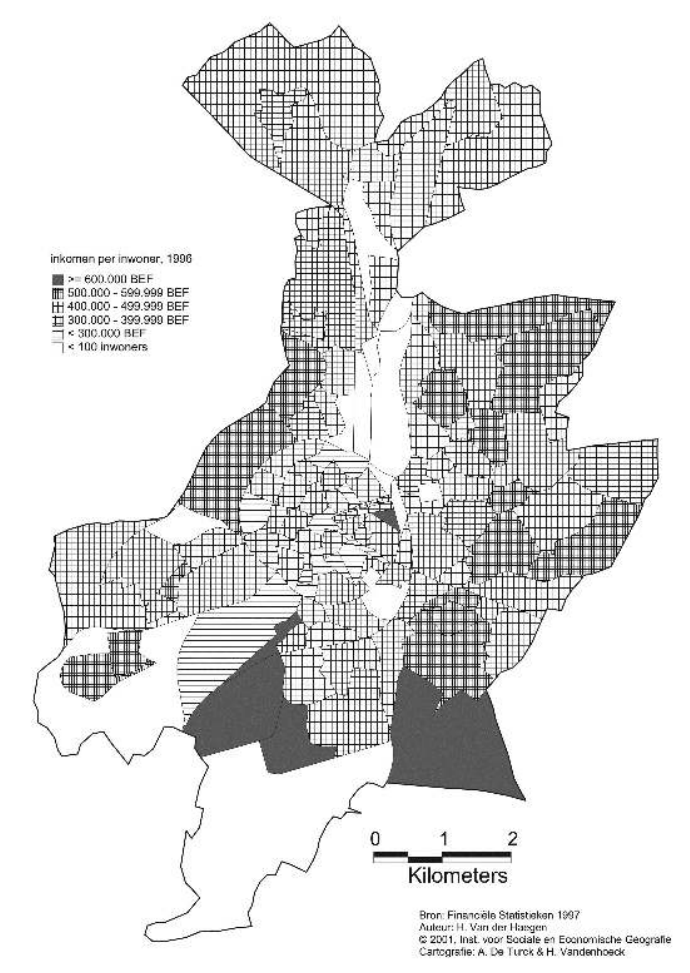

17 Tenslotte dient gewezen op de zeer goede verkeersontsluiting ten opzichte van Brussel en Zaventem die leidde tot een sterk groeiende woonfunctie voor Brusselse werkforensen met relatief hoog welstandsniveau. Dit betekent dat velen Leuven wegens haar uitstekend en kwalitatief hoog woon- en leefmilieu als Nederlandstalig alternatief van het meer en meer Franstalig en wat de bevolking betreft in alle opzichten geinternatio-naliseerd Brussel beschouwen. Al met al wordt hiermede de gedachte van een dubbelstad BrusselLeuven verder inhoud gegeven.

\section{De verkiezingsuitslagen}

Een overzicht van de verkiezingsuitslagen tussen 1987 en 1995 die het materiaal leveren voor onze uiteenzettting, wordt in tabel 1 weergegeven. Het gebruik van deze periode heeft het voordeel dat het interval tussen de gemeente- en kamerverkiezingen telkens slechts een jaar bedroeg en vergelijkingen dus mogelijk zijn. 
Tabel 1. Uitslagen verkiezingen in Leuven (\%).

\begin{tabular}{|l|c|c|c|c|}
\hline Partijen & Kamer 1987 & Gemeente 1988 & Gemeente 1994 & Kamer 1995 \\
\hline C.V.P. & 30 & 39 & 27 & 23 \\
\hline S.P. & 24 & 25 & 40 & 31 \\
\hline V.L.D. & 18 & 16 & 12 & 17 \\
\hline Agalev & 10 & 10 & 9 & 10 \\
\hline V.U. & 12 & 6 & 4 & 8 \\
\hline Vlaams Blok & 2 & 2 & 5 & 8 \\
\hline
\end{tabular}

Tabel 1 toont:

- Dat C.V.P. en S.P. samen steeds meer dan de helft van de stemmen behaalden, voor de gemeente zelfs bijna tweederde, waarbij in 1987/88 de C.V.P. en in 1994/95 de S.P. de voornaamste partij was.

- Dat deze twee partijen op het lokale plan het duidelijkst aanwezig zijn aangezien zij telkens voor de gemeenteraad beter scoren dan voor de kamer en dit in tegenstelling tot de andere partijen. C.V.P. en S.P. bepaalden het Leuvense politieke spannings- maar ook beleidsveld.

20 Alle partijen behaalden stemmen in iedere kieswijk zoals blijkt uit figuur 3, met resultaten van de gemeenteraadsverkiezing in 1994. Deze figuur toont tevens dat er heel wat verschillen optreden tussen de onderscheiden kieswijken. Tevens verduidelijkt de figuur dat de grootste concentratie van kiezers, zoals het voor een stedelijk gebied hoort, vrij centraal ligt.

Figuur 3. Resultaten per partij: Gemeenteraadsverkiezing 1994.

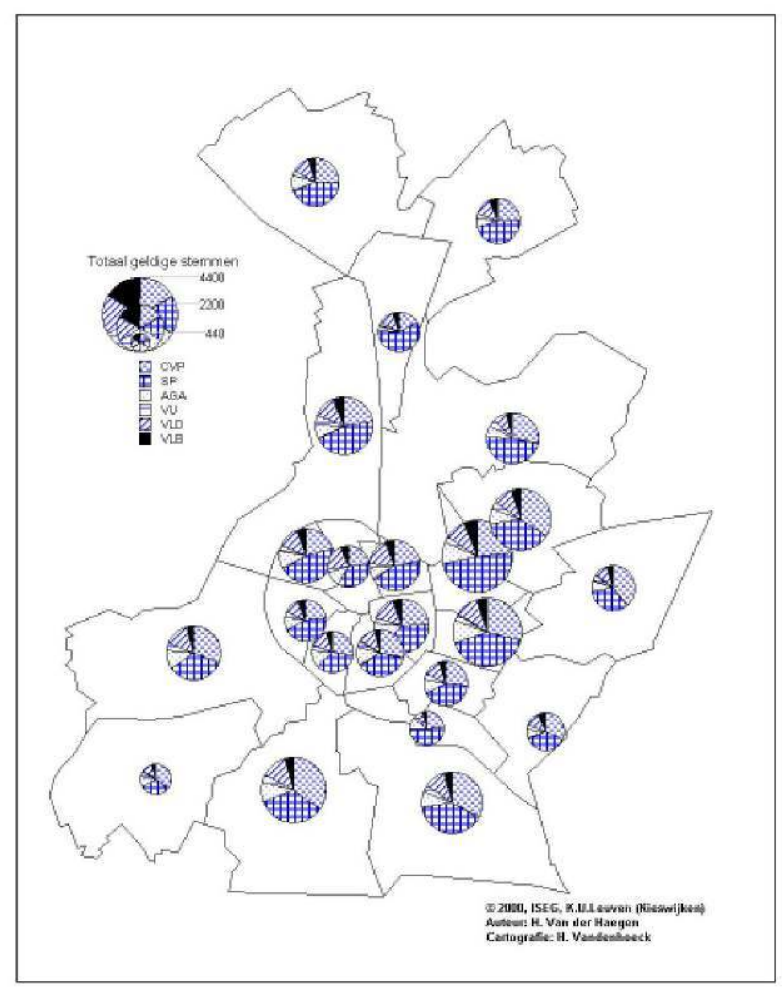


Figuur 4. Gemeenteraadsverkiezing 1988. Verhouding tussen de beide grootste partijen.

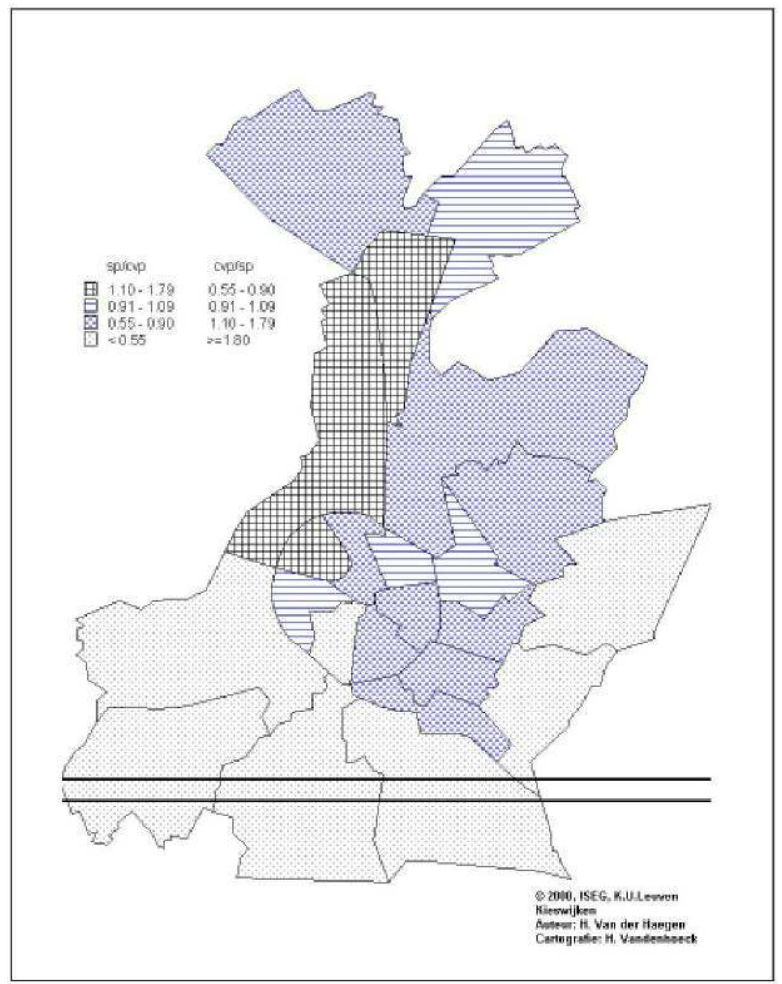

21 De differentiatie die optreedt in het kiesgedrag tussen de verschillende wijken kan het best bondig weergegeven worden door de resultaten van de twee grootste partijen en hun onderlinge verhouding te analyseren. Een bespreking waarbij de andere partijen betrokken worden zou te detaillistisch zijn en te veel kaartmateriaal eisen. Alleen de gunstige resultaten van de liberale V.L.D. in de centrale stadswijk heeft trouwens een ruimtelijke relevantie.

De gemeenteraadsverkiezing van 1988 (figuur 5) geeft een vrij traditioneel beeld voor die periode: overwicht van de C.V.P. die op Leuvens niveau zelfs ruim $50 \%$ meer stemmen behaalde dan de S.P. en over een sterke lokale voorman beschikte met oud-burgemeester A. Vansina. Het C.V.P.-overwicht was bijzonder duidelijk in het zuiden, waar Heverlee steeds een zekerheid was, iets minder in het oosten, maar ook in Wijgmaal. De socialisten overwegen enkel, maar dan ook in al de kieswijken van de oude sterk socialistische gemeente Wilsele en in iets mindere mate in een paar traditionele arbeidersbuurten van Leuven-stad en in het centrum van Kessel-Lo, oude socialistische burcht. 
Figuur 5. Gemeenteraadsverkiezing 1994. Verhouding tussen de beide grootste partijen.

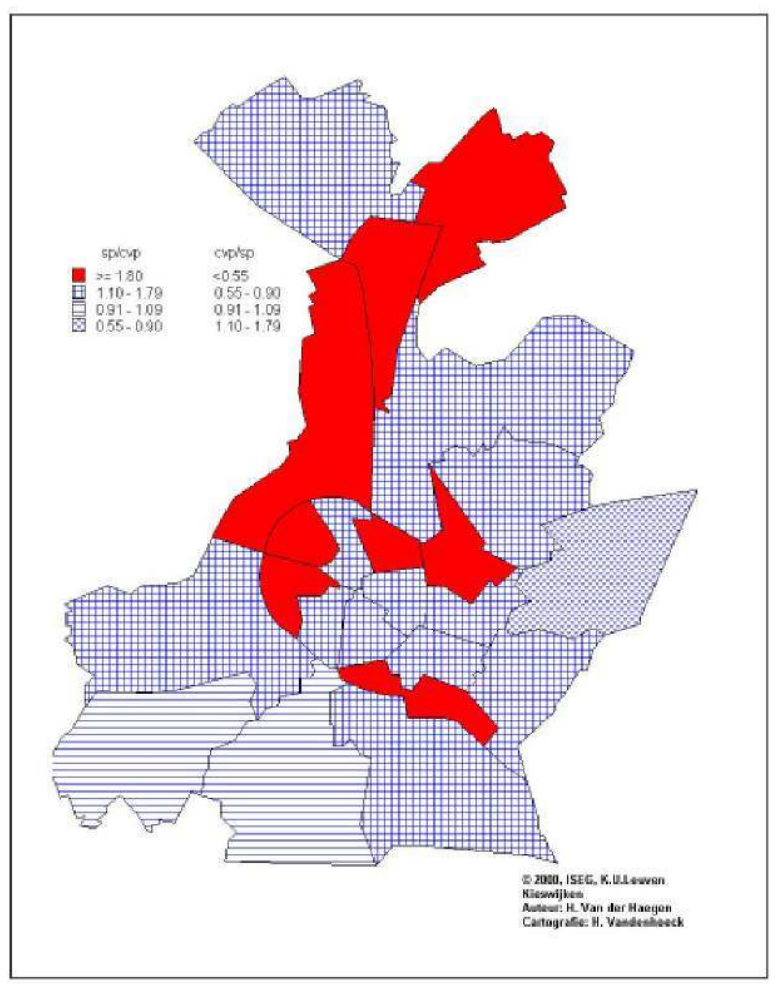

De gemeenteraadsverkiezing van 1994 (figuur 6) geeft globaal dezelfde ruimtelijke contrasten en toch een ander beeld: nu hebben de socialisten $60 \%$ meer stemmen behaald en overwegen, op een paar zuidelijke Heverleese wijken (o.a. de residentiezone, aansluitend bij de universitaire campus en Heverleebos en Egenhoven) alsook het vroegere landelijke Korbeek-Lo na. Hun boegbeeld L. Tobback staat op het toppunt van zijn nationale politieke faam en heeft in Leuven de partij goed uitgebouwd. Hij scoort zelfs in een paar traditionele C.V.P.-burchten zoals het zuiden van Heverlee goed, terwijl het overwicht op de C.V.P. in de vanouds socialistische wijken verpletterend is (figuur 7 en 8). Globaal is het zo dat in de noordelijke helft van Leuven, de S.P.-zone bij uitstek, de partij een aangroei kent met 10 tot $15 \%$ van de stemmen. In het gehele zuiden, met inbegrip van de zuidoostelijke delen van de binnenstad (het burgerlijke zogenaamd nieuw kwartier) is er sprake van een werkelijke doorbraak met een groei van 15 à 30\% van de stemmen. Daar is ook het verlies van de C.V.P. het meest uitgesproken. 
Figuur 6. Gemeenteraadsverkiezing 1994. Aantal en percentage SP.

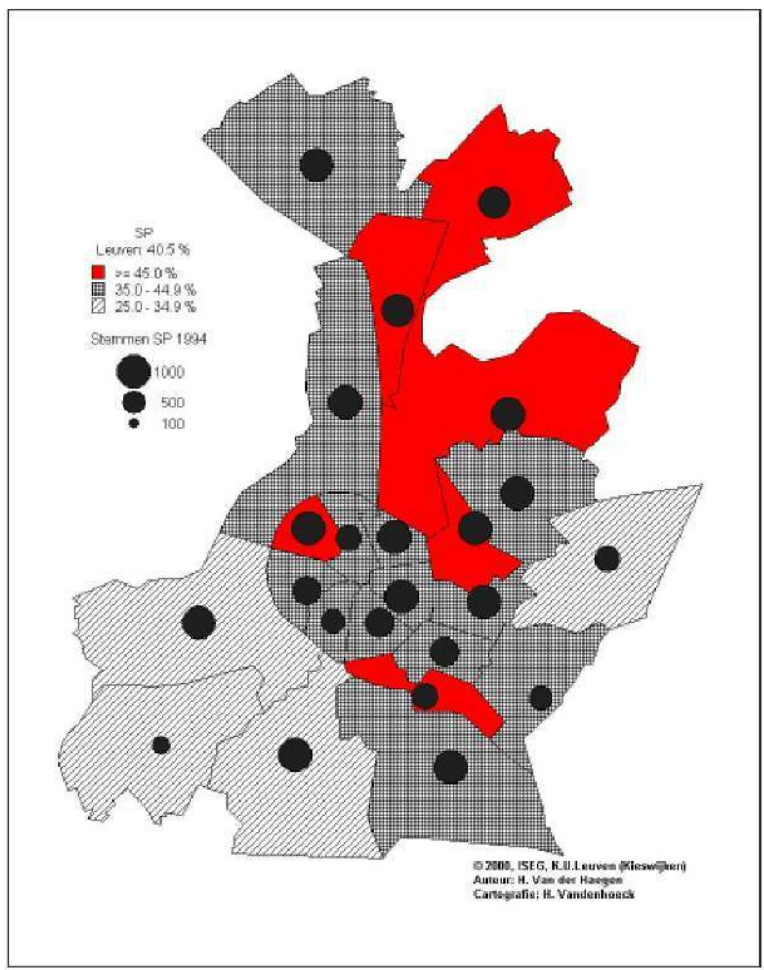

Figuur 7. Evolutie verkiezingsresultaten SP. Gemeenteraad 1994 t.o.v. 1988.

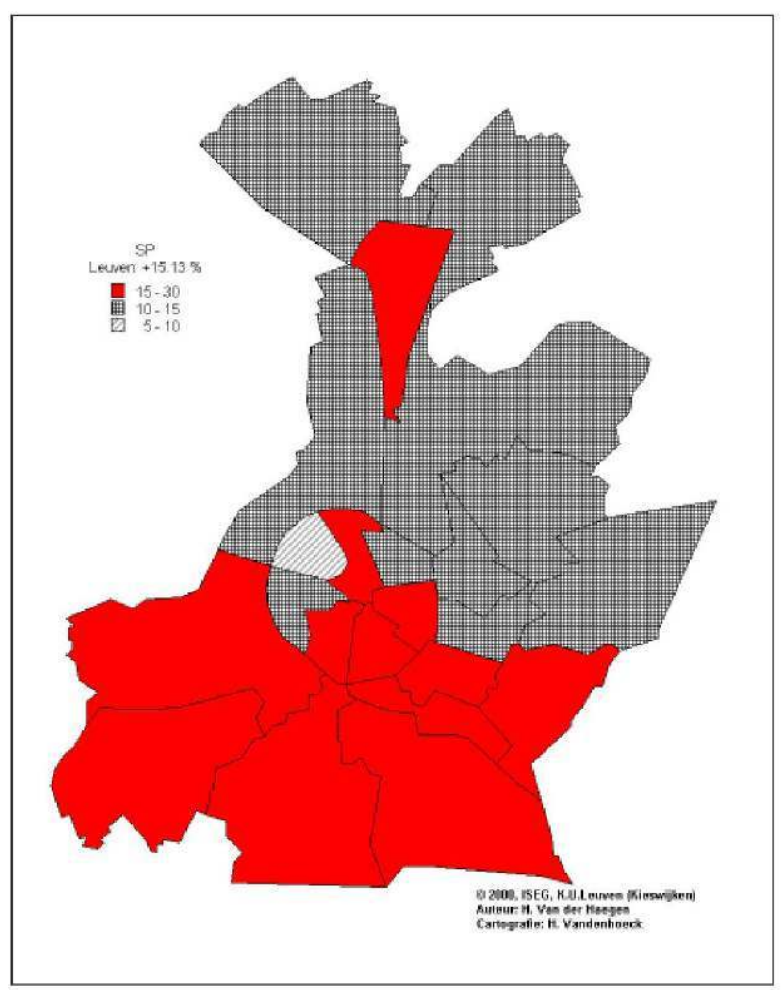




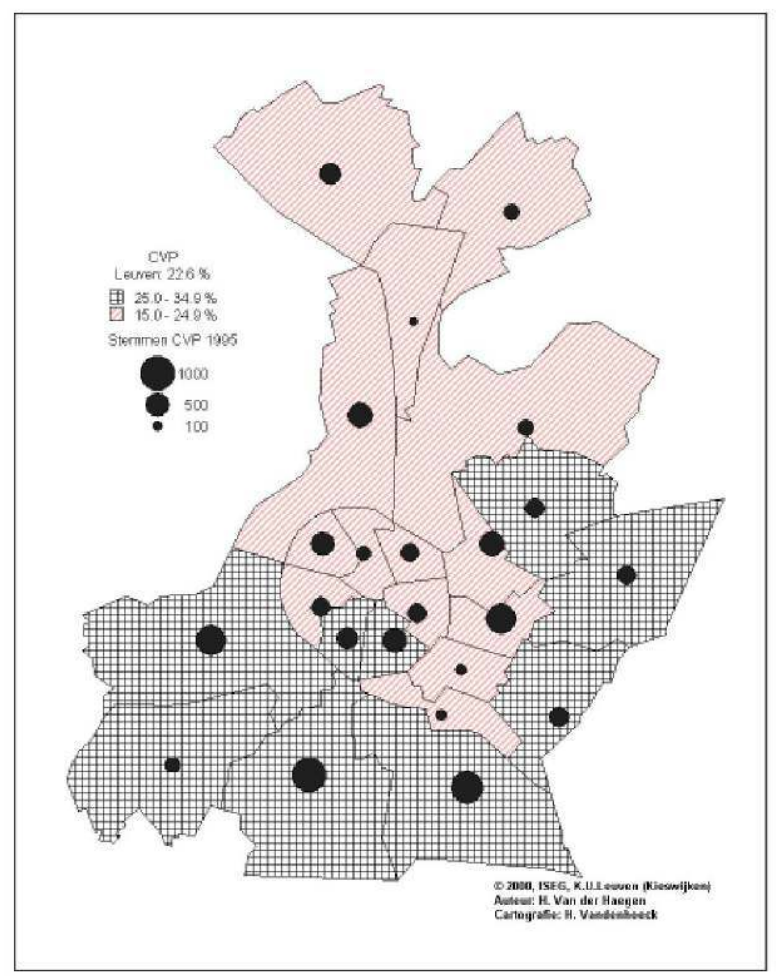

De confrontatie van de kamerverkiezing van 1995 met de gemeenteverkiezing van 1994, zowel voor C.V.P. (figuur 9) als de S.P., tonen dat ze beide minder goed scoren zoals reeds bleek uit tabel 1. Naast de algemene politieke evolutie is dit het gevolg van de afwezigheid van sterke persoonlijkheden bij de andere partijen op gemeentelijk vlak terwijl deze wel aanwezig zijn op het niveau van de kamer. Ter illustratie merken we op dat de V.L.D. in 1995 bij de kamerverkiezing bijna 50\% meer behaalde dan bij de gemeenteverkiezing in 1994 (effect Rik Daems) en de V.U. haar aandeel zelfs verdubbelde (effect Willy Kuypers). Het is duidelijk dat bij deze verkiezingen de Leuvense gemeentelijke tenoren alhoewel sommigen aanwezig waren op de kieslijsten, maar dan toch - op Tobback na - op minder zichtbare plaatsen niet dezelfde attractie uitoefenen, hetgeen gezien de aard van de verkiezingen (federaal en niet gemeentelijk) maar normaal is. Dit betekent wel dat zowel in 1987 als in 1995 beide partijen hun aandeel bij de kiezers zien dalen. In 1988/87 (samen) van $64 \%$ tot $54 \%$, in $1995 / 94$ zelfs van $67 \%$ tot $54 \%$. 
Figuur 9. Kamerverkiezing 1995. Aantal en percentage SP.

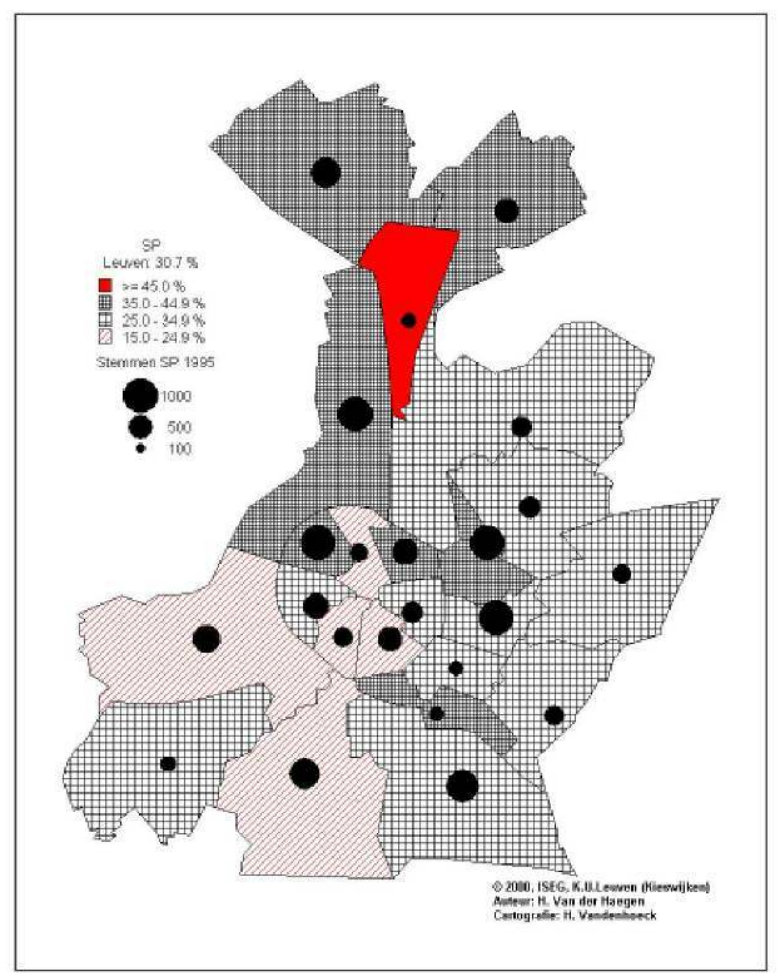

Bij de analyse per wijk blijkt dat de teruggang bij de S.P. niet alleen het sterkst is $(-9,8 \%$ t.o.v. $-4,10 \%$ bij de C.V.P.), maar bovendien het meest uitgesproken in het zuiden van Leuven. Met andere woorden de traditionele strongholds verdedigen zich het best en de doorbraak die de S.P. er in 1994 realiseerde wordt afgezwakt.Dat de teruggang van de C.V.P. bij de kamerverkiezing (figuur 10) beperkter is kan dan weer beinvloed zijn door het feit dat zijn bekendste politicus (M. Eyskens) zich vooral federaal en nauwelijks gemeentelijk affirmeerde. 


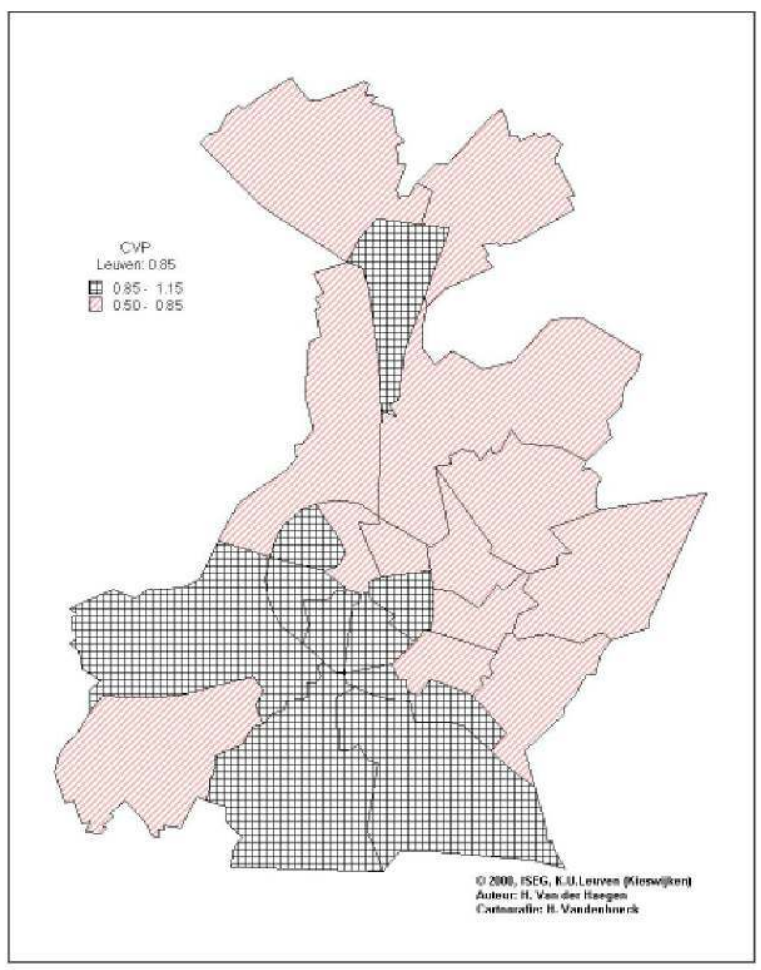

\section{Besluit}

De analyse van de verkiezingen op wijkniveau illustreert duidelijk dat bij de interne variatie die binnen een gemeente optreedt er een verband is zowel met de oude socioeconomische differentiatie binnen de gemeente als met de vroegere gemeentelijke politieke structuur.

Een vergelijking tussen gemeentelijke en kamerverkiezingen bevestigt dat de invloed van de lokale politici zich op het niveau van de gemeente sterk laat aflezen.

\section{BIBLIOGRAPHIE}

KNOPS G. (1972), «De wijk Diependaal en haar bewoners», in Tijdschrift van de Belgische Vereniging voor Aardrijkskun-dige Studies, pp. 93-103.

VAN der HAEGEN H. (1975), «Leuven en zijn stadsgewest», in Leuven, Survey van een stadsgewest, dl 1, Leuven.

VAN der HAEGEN H. (1974), «De ontwikkeling van de bebouwing in Leuven na 1830», in Leuven, een stad die groeit, Leuven, pp. 105-147. 


\section{RÉSUMÉS}

Het Leuvense intern gedifferentieerd kiespatroon werd voor de periode van 1987 tot 1995 geanalyseerd via partiële resultaten per wijk, die door de getuigen van de partijen werden genoteerd in de telbureaus.

Het ruimtelijk patroon weerspiegelt nog steeds het traditionele socio-economisch patroon van de stad met een sterke arbeidscomponent in het noorden en een residentieel gebied in het zuiden. Historisch bepaald kiesgedrag, de aanwezigheid van de Christelijke Volkspartij die beoogt standendoorbrekend te zijn, maar ook de ontwikkeling van nieuwe al of niet residentiële buurten en vooral de aanwezigheid van politieke boegbeelden bepalen, vooral op wijkniveau, sterk de resultaten.

The results of municipal and federal elections between 1987 and 1995 could be obtained in Leuven at neighbourhood level thanks to the notes of party witnesses in the polling stations. The results show that the traditional socio-economic structure of the city, with a strong concentration of working class people in the north and more middle class areas in the south, still determines voting behaviours. Moreover, these behaviours are explained, especially at local level, by the development of new neighbourhoods, the presumption of the Christian democratic party to break through the class structures and the presence of politicians with strong reputation.

Political Parties: C.V.P.: Christian democrat; S.P.: socialist; V.L.D.: liberal; Agalev: green; V.U: Flemish nationalist; Vlaams Blok: ultra right populist

INDEX

Keywords : electoral geography, urban voting behaviour, Leuven (Louvain) motsclesnl electorale geografie, stedelijk kiespatroon, Leuven

\section{AUTEUR}

\section{HERMAN VAN DER HAEGEN}

K.U.Leuven, Instituut voor Sociale en Economische Geografie, Herman.Vanderhaegen@geo.kuleuven.ac.be 